\title{
Population Structure of Brown Rot Fungi on Stone Fruits in China
}

Xiao-qiong Zhu, Department of Plant Pathology, China Agricultural University, Beijing 100193; Xiao-yu Chen, Beijing Plant Protection Station, Beijing 100029; and Li-yun Guo, Department of Plant Pathology, China Agricultural University

\begin{abstract}
Zhu, X.-Q., Chen, X.-Y., and Guo, L.-Y. 2011. Population structure of brown rot fungi on stone fruits in China. Plant Dis. 95:1284-1291.

In total, 455 Monilinia isolates from stone fruits collected from several provinces (cities) in China from 2003 to 2009 were identified to species based on morphological characteristics, molecular identification, and the sequence of the internal transcribed spacer (ITS) regions 1 and 2 and the 5.8S gene of the ribosomal RNA. Overall, four species were detected (Monilinia fructicola, M. fructigena, M. laxa, and Monilia polystroma). M. fructicola was the most prevalent (93.0\%) followed by M. fructigena (4.8\%), M. laxa (2.0\%), and Monilia polystroma $(0.2 \%)$. M. fructicola and M. fructigena were found on peach, plum, and apricot; $M$. laxa was found only on apricot, cherry (in an organic

plum in Heilongjiang. The pathogenicity of Monilinia fructicola, M. laxa, and $M$. fructigena did not significantly differ on wounded nectarine and apricot, indicating that the differences in frequency of occurrence were not linked to virulence. Phylogenetic analysis based on ITS sequences showed that the isolates of M. laxa and M. fructigena from China differed from isolates of these species from other countries, and that the difference led to the separation of the isolates from China and those from other countries into different phylogenetic groups. Further study is needed to determine whether they are cryptic species.
\end{abstract} orchard), and wild peach; and Monilia polystroma was found only on
Brown rot is one of the most important diseases of stone fruits (Prunus spp.) worldwide (3). Under favorable conditions, it causes severe losses and damage to fruit crops and to the trees themselves (24). The causal pathogens of brown rot of stone and pome fruits include four closely related fungi: Monilinia fructicola (G. Winter) Honey, M. laxa (Aderh. \& Ruhland) Honey, M. fructigena (Aderh. \& Ruhland) Honey, and Monilia polystroma G. Leeuwen $(3,30)$. $M$. polystroma is a new asexual species first found in Japan (30) and then in Hungary and China $(28,36)$. The distribution of these species differ across the world $(3,30)$, and some are quarantine pests in specific regions. For example, M. fructicola is a quarantine pathogen in the European Union $(7,22,23)$ but was recently found in peach orchards of southern France (22) and Italy (26). $M$. fructigena is a quarantine pathogen in the United States and Australia (3).

China is one of the major stone fruit producers, and brown rot is an important disease in many of its stone-fruit-growing areas. The earliest record of brown rot on stone fruit in China can be dated to 1920 (4). From the1920s to 1950s, brown rot was reported on stone fruits, including apricot (Prunus armeniaca L.), wild apricot $(P$. armeniaca $\mathrm{L}$. var. ansu Maxim), sour cherry (P. cerasus L.), peach (P. persica Stokes), and flat peach (P. communis Fritsch), and the causal pathogen was referred to as Sclerotinia laxa (4). In a study from 1994 to 1996, M. laxa and M. fructigena were detected in China (31). In 2007, M. fructicola was listed as a quarantine pest in China (1), although this species was found in a peach orchard in a Beijing suburb in 2003 (35). The recent discovery of M. fructicola suggests that either the species composition of brown rot fungi in China has changed or that the population structure of brown rot fungi is more complex in China than previously recognized. Therefore, the objectives of this study were to (i) identify the Monilinia spp. in China using morphological and molecular methods and (ii) determine the prevalent species and their pathogenicity.

Corresponding author: L.-Y. Guo,

E-mail: ppguo@cau.edu.cn,ppguoly@126.com

Accepted for publication 1 June 2011.

doi:10.1094/PDIS-02-11-0079

(c) 2011 The American Phytopathological Society

\section{Materials and Methods}

Survey. In a survey carried out from 2003 to 2009, fruit with symptoms of brown rot were collected from orchards located in the following 12 provinces or cities: Beijing, Shandong, Hebei, Shanghai, Zhejiang, Jiangsu, Henan, Gansu, Sichuan, Yunnan, Liaoning, and Heilongjiang. The number of fruit collected from each orchard depended on the extent of the disease and the number of Prunus spp. if several crops were present in one orchard (Table 1). In the laboratory, a sterilized wire loop was used to transfer spores from the fruit (or mummy) onto the surface of water agar (WA) in petri dishes. After 16 to $24 \mathrm{~h}$ at $22 \pm 2{ }^{\circ} \mathrm{C}$, individual germinated spores were aseptically transferred from the WA to potato dextrose agar (PDA) in petri dishes. The isolates were then stored on PDA slants at $4^{\circ} \mathrm{C}$, and representative cultures were deposited in the China Forestry Culture Collection Center. The source and host of the isolates are listed in Tables 2 and 3; reference isolates are listed in Table 3.

Morphological characterization. The colony morphology of each isolate was determined on PDA. A plug (5 $\mathrm{mm}$ in diameter) was cut from the edge of a 4-day-old colony and placed in the center of a petri dish $(9 \mathrm{~cm}$ in diameter) containing about $15 \mathrm{ml}$ of PDA. Three replicate dishes were used for each isolate. The dishes were kept at $22 \pm 2{ }^{\circ} \mathrm{C}$ with $12 \mathrm{~h}$ of near-UV light (wavelength $365.5 \mathrm{~nm}$ ) and $12 \mathrm{~h}$ of darkness. After 6 days, the seven critical characters described by Byrde and Willettes (3) and Lane (17) were determined for each isolate.

DNA extraction. Mycelia from cultures grown in pea broth (10) at $22 \pm 2{ }^{\circ} \mathrm{C}$ for 3 to 5 days in darkness were collected by filtration. DNA was extracted following a method that was modified from Murray and Thompson (21) and Wilson (33). The concentration of DNA was quantified by electrophoresis in $1 \%$ agarose gels along with known quantities of $\lambda$ DNA (Takara Bio. Inc., Japan).

PCR amplification and DNA sequencing. The species-specific primers developed by Ioos and Frey (16) were used. Polymerase chain reaction (PCR) amplification was performed in a $25-\mu \mathrm{l}$ volume containing $2.0 \mathrm{mM} \mathrm{MgCl} 2,1.0 \mathrm{U}$ of Taq polymerase, $200 \mu \mathrm{M}$ each dNTP, $0.2 \mu \mathrm{M}$ each of the specific primers, and 10 to $20 \mathrm{ng}$ of genomic DNA. PCR cycling parameters were $94^{\circ} \mathrm{C}$ for $3 \mathrm{~min}$, followed by 30 cycles $\left(94^{\circ} \mathrm{C}\right.$ for $30 \mathrm{~s}, 67.5^{\circ} \mathrm{C}$ for $30 \mathrm{~s}$, and $72^{\circ} \mathrm{C}$ for $1.5 \mathrm{~min}$ ), and a final extension of $72^{\circ} \mathrm{C}$ for $10 \mathrm{~min}$ in an Icycler Thermal Cycler (Bio-Rad Laboratories Inc., Hercules, CA). PCR products, which were about $350 \mathrm{bp}$, were separated by elec- 
trophoresis in $1.5 \%$ agarose gels in Tris-borate-EDTA buffer and were photographed with a Multilmage Light Cabinet (Alpha Innotech Corporation) after staining with ethidium bromide.

Isolates that could not be identified according to morphological characteristics or species-specific PCR amplification were subjected to more DNA tests. The ribosomal DNA of these isolates was amplified with primers ITS1 and ITS4 (32) using the same PCR protocol described above, except that the annealing temperature was $55^{\circ} \mathrm{C}$. The amplified fragments were purified using the PCR product Purification Kit (Dingguo Inc., Beijing), and DNA sequencing was performed by the Beijing Sunbiotech Co. Ltd.

Phylogenetic analysis. The ITS regions were sequenced for 39 isolates, including 30 representative isolates collected from different locations and 9 isolates that were unidentifiable using speciesspecific primers. The ITS sequences of the test strains and the reference isolates and the reference sequences retrieved from GenBank (Table 3) were used to construct the phylogenetic tree. The sequence alignment was done using BioEdit (11) with manual adjustment. The maximum parsimony (MP) analyses were performed by heuristic search in PAUP $4.0 b 10$ (29). Gaps were treated as a fifth character weight, and all characters were of equal weight but uninformative characters were excluded. Bootstrap values were estimated by 1,000 replications to assess the robustness of the topology.

Pathogenicity tests. The pathogenicity of nine isolates representing different species and obtained from different hosts and locations in China was tested on nectarine and apricot fruits (Table 3 ); the purpose was to determine whether the prevalence of $M$. fructicola was associated with increased virulence. For isolates of M. fructicola, conidia from 6-day-old cultures on PDA were dislodged by washing the culture surface with 5 to $10 \mathrm{ml}$ of steriledistilled water. Because M. fructigena and M. laxa produced few conidia on PDA, the conidia of these species were obtained from pear fruit that had been inoculated 8 days earlier. The conidial suspension was filtered through two layers of muslin cloth and then adjusted to $1 \times 10^{4}$ conidia $\mathrm{ml}^{-1}$.

To test the pathogenicity of isolates on apricot, fruit were first surface sterilized with $0.128 \% \mathrm{NaClO}$ for $15 \mathrm{~min}$ and then rinsed three times with sterile-distilled water. Each fruit was wounded with a nail (2-mm diameter and 3-mm depth) before $5 \mu \mathrm{l}$ of the spore suspension was placed on each wound. Fruit inoculated with sterile-distilled water were used as controls.

To test the pathogenicity of isolates on nectarine, mature fruit were sterilized and wounded as described for apricot. A mycelial plug ( $5 \mathrm{~mm}$ in diameter) cut from the margin of a 6-day-old culture on PDA was placed on each wound. Fruit inoculated with PDA

Table 1. Geographic origin of Monilinia spp. isolates collected from stone fruit in China

\begin{tabular}{|c|c|c|c|}
\hline Fruit ${ }^{\mathrm{a}}$ & Region & $\begin{array}{c}\text { Number of } \\
\text { orchards }\end{array}$ & $\begin{array}{c}\text { Number of } \\
\text { isolates }\end{array}$ \\
\hline \multirow[t]{10}{*}{ Peach } & Beijing & 47 & 342 \\
\hline & Shandong & 11 & 42 \\
\hline & Hebei & 2 & 9 \\
\hline & Yunnan & 2 & 8 \\
\hline & Shanghai & 2 & 4 \\
\hline & Zhejiang & 3 & 3 \\
\hline & Gansu & 2 & 4 \\
\hline & Liaoning & 1 & 1 \\
\hline & Unknown & 2 & 3 \\
\hline & Total & 71 & 416 \\
\hline \multirow[t]{5}{*}{ Plum } & Beijing & 6 & 13 \\
\hline & Shandong & 1 & 11 \\
\hline & Gansu & 1 & 1 \\
\hline & Heilongjiang & 1 & 1 \\
\hline & Total & 9 & 26 \\
\hline Apricot & Beijing & 3 & 7 \\
\hline Cherry & Beijing & 3 & 5 \\
\hline Wild peach & Shandong & 1 & 1 \\
\hline
\end{tabular}

a "Peach" includes peach, nectarine, flat peach, and flat nectarine. plugs without fungus were used as controls. Each of the nine isolates was represented by three replicates (five fruit per replicate) for each Prunus spp. The fruit were placed on two layers of moist paper towels on a wire rack in a plastic container at room temperature $\left(24.5 \pm 2{ }^{\circ} \mathrm{C}\right)$. Three replicated containers were used for each isolate. The width and length of lesions on the inoculated fruit were measured 2 and 4 days after inoculation. Lesion expansion rate (millimeters per day) was calculated according to the difference in lesion size between the two measuring dates. Treatments were compared by analysis of variance (ANOVA) using the PROC procedure of SAS (SAS Institute, Cary, NC), and multiple comparisons among the means were conducted using $t$ tests (least significant difference) when effects were statistically significant at the 0.05 level. The experiments were repeated at least once.

\section{Results}

Species identification of brown rot fungi in China. Infected fruit showing brown rot symptoms or mummified fruit with sporulation were collected from 9 of 12 provinces (cities), which included Beijing, Shandong, Hebei, Shanghai, Zhejiang, Gansu, Yunnan, Liaoning, and Heilongjiang. In total, 455 isolates were identified (Table 2). Of these, 227 were identified based only on morphology, 228 were identified using the molecular method developed by Ioos and Frey (16), and 168 were identified based on both morphology and the molecular methods.

On PDA dishes, 367 of 395 isolates developed grayish zonate colonies with more or less even margins and with abundant sporulation on the surface (Fig. 1); these isolates were identified as $M$. fructicola. The eight isolates that were light gray to dark gray with lobed margins and sparse sporulation (Fig. 1) were tentatively identified as $M$. laxa. Twenty isolates that had white to grayish colonies with sparse sporulation and entire margins (like M. fructicola) were identified as $M$. fructigena.

In total, 228 isolates, including 168 isolates identified by morphological characteristics, were identified with the molecular method described by Ioos and Frey (16). According to this method, PCR with primer pair ITS1Mfcl/ITS4Mfcl detects $M$. fructicola, PCR with primer pair ITS1Mlx/ITS4Mlx detects $M$. laxa, and PCR with primer pair ITS1Mfgn/ITS4Mfgn detects $M$. fructigena. When the 228 isolates were amplified with the three primer pairs, 203 isolates, including 145 isolates identified as M. fructicola by morphological characteristics, generated a PCR product only with primer pair ITS1Mfcl/ITS4Mfcl, six isolates identified as M. laxa based on culture morphology generated PCR products only with primer pair ITS1Mlx/ITS4Mlx, and 10 isolates identified as $M$.

Table 2. Geographic distribution of Monilinia spp. isolates from stone fruit in China

\begin{tabular}{lllc}
\hline Species & Location & Host $^{\text {a }}$ & $\begin{array}{c}\text { Number } \\
\text { of isolates }\end{array}$ \\
\hline Monilinia fructicola & Beijing & Peach & 338 \\
& Beijing & Plum & 11 \\
& Beijing & Cherry & 2 \\
& Shandong & Peach & 42 \\
& Shandong & Plum & 10 \\
& Hebei & Peach & 9 \\
& Shanghai & Peach & 4 \\
& Zhejiang & Peach & 3 \\
M. laxa & Liaoning & Peach & 1 \\
& unknown & Peach & 3 \\
& Shandong & Wild peach & 1 \\
M. fructigena & Beijing & Apricot & 5 \\
& Beijing & Cherry & 3 \\
& Beijing & Peach & 4 \\
& Beijing & Apricot & 2 \\
& Beijing & Plum & 3 \\
Monilia polystroma & Yunnan & Peach & 8 \\
& Gansu & Peach & 4 \\
& Gansu & Plum & 1 \\
& Heilongjiang & Plum & 1 \\
\hline
\end{tabular}

a "Peach" includes peach, nectarine, flat peach, and flat nectarine. 
Table 3. Isolates and sequences of Monilinia spp. used in the pathogenicity test and for phylogenetic analysis

\begin{tabular}{|c|c|c|c|c|c|}
\hline Isolate & Location & Host $^{\mathbf{a}}$ & Species & $\begin{array}{c}\text { GenBank accession } \\
\text { number }\end{array}$ & $\begin{array}{l}\text { Phylogenetic } \\
\text { group }\end{array}$ \\
\hline \multicolumn{6}{|l|}{ Isolates from China } \\
\hline ML4 & Mentougou, Beijing & Apricot & Monilinia laxa & HQ846955 & II \\
\hline ME1 & Miyun, Beijing & Apricot & M. laxa & HQ846953 & II \\
\hline $\mathrm{JX} 3^{\mathrm{b}}$ & Miyun, Beijing & Apricot & M. laxa & HQ846954 & II \\
\hline $\mathrm{JX} 9^{\mathrm{c}}$ & Miyun, Beijing & Apricot & M. laxa & HQ846952 & II \\
\hline $\mathrm{BX} 5^{\mathrm{b}}$ & Pinggu, Beijing & Apricot & M. fructigena & HQ846961 & $\mathrm{V}$ \\
\hline BHY1 & Haidian, Beijing & Cherry & M. fructicola & HQ846927 & VI \\
\hline BLG3 & Haidian, Beijing & Cherry & M. fructicola & HQ846922 & VI \\
\hline MY11 $1^{b}$ & Miyun, Beijing & Cherry & M. laxa & HQ846951 & II \\
\hline $\mathrm{T} 18$ & Changping, Beijing & Peach & M. fructicola & HQ846940 & VI \\
\hline $\mathrm{PBF}^{\mathrm{c}}$ & Fangshan, Beijing & Peach & M. fructicola & HQ846936 & VI \\
\hline $320020^{\mathrm{b}, \mathrm{c}}$ & Pinggu, Beijing & Peach & M. fructicola & HQ846925 & VI \\
\hline $332331^{\mathrm{b}, \mathrm{c}}$ & Pinggu, Beijing & Peach & M. fructicola & HQ846926 & VI \\
\hline $\mathrm{GP} 3^{\mathrm{b}, \mathrm{c}}$ & Yanqing, Beijing & Peach & M. fructigena & HQ846957 & $\mathrm{V}$ \\
\hline GP13 & Yanqing, Beijing & Peach & M. fructigena & HQ846958 & V \\
\hline GP18b & Yanqing, Beijing & Peach & M. fructigena & HQ856917 & $\mathrm{V}$ \\
\hline PA18 & Pinggu, Beijing & Peach & M. fructicola & HQ846935 & VI \\
\hline $\mathrm{CH} 2$ & Changping, Beijing & Plum & M. fructigena & HQ846928 & VI \\
\hline HAG7 & Changping, Beijing & Plum & M. fructicola & HQ846933 & VI \\
\hline FH1 & Huairou, Beijing & Plum & M. fructicola & HQ846932 & VI \\
\hline STL1 $^{\mathrm{c}}$ & Miyun, Beijing & Plum & M. fructigena & HQ846960 & $\mathrm{V}$ \\
\hline $\mathrm{DH} 41^{\mathrm{c}}$ & Pinggu, Beijing & Plum & M. fructicola & HQ846931 & VI \\
\hline GS3 & Yanqing, Beijing & Plum & M. fructigena & HQ846956 & $\mathrm{V}$ \\
\hline GDT1 & Dongzhiyuan, Gansu & Peach & M. fructigena & HQ846963 & V \\
\hline $\mathrm{GND}^{\mathrm{b}}$ & Lanzhou, Gansu & Peach & M. fructigena & HQ846962 & $\mathrm{V}$ \\
\hline HeBSM11 & Hebei & Peach & M. fructicola & HQ846934 & VI \\
\hline $\mathrm{PJH} 2$ & Handan, Hebei & Peach & M. fructicola & HQ846937 & VI \\
\hline HML3 & Mudanjiang, Heilongjiang & Prunus aitianli & Monilia polystroma & GU067539 & IV \\
\hline 5-10HUANG & Jinan, Shandong & Peach & M. fructicola & HQ846924 & VI \\
\hline $\mathrm{CX} 25$ & Laiyang, Shandong & Peach & M. fructicola & HQ846930 & VI \\
\hline SPT16 & Pingyi, Shandong & Peach & M. fructicola & HQ846920 & VI \\
\hline PLY14 ${ }^{\mathrm{b}}$ & Yantai, Shandong & Peach & M. fructicola & HQ846938 & VI \\
\hline SLT2 & Yiyuan, Shandong & Peach & M. fructicola & HQ846939 & VI \\
\hline $\mathrm{CX} 3$ & Laiyang, Shandong & Plum & M. fructicola & HQ846929 & VI \\
\hline STT2 & Taishan, Shandong & Wild peach & M. laxa & HQ846950 & VI \\
\hline $\mathrm{ZJMf}^{\mathrm{c}}$ & Hangzhou, Zhejiang & Peach & M. fructicola & HQ846923 & VI \\
\hline MFLS1 & Lishui, Zhejiang & Peach & M. fructicola & HQ846941 & VI \\
\hline YCT3 & Chuxiong, Yunnan & Unknown & M. fructigena & HQ846965 & $\mathrm{V}$ \\
\hline YHT3 & Honghezhou, Yunnan & Unknown & M. fructigena & HQ846959 & $\mathrm{V}$ \\
\hline SFT1 & Shanghai & Unknown & M. fructicola & HQ846921 & VI \\
\hline \multicolumn{6}{|l|}{ Reference isolates } \\
\hline HAY30 & Unknown & Rape & Sclerotinia sclerotiorum & HQ846942 & Outgroup \\
\hline BCE4 & Beijing & Tomato & Botrytis cinerea & HQ846943 & Outgroup \\
\hline $\mathrm{Ft}$ & France & Unknown & M. fructicola & HQ846967 & VI \\
\hline NE18 & New Zealand & Unknown & M. fructicola & HQ846919 & VI \\
\hline LVN8 & USA & Unknown & M. fructicola & HQ846966 & VI \\
\hline $\mathrm{P} 1$ & France & Unknown & M. fructigena & HQ846946 & III \\
\hline GENA4 & Italy & Unknown & M. fructigena & HQ846945 & III \\
\hline P3 & France & Unknown & M. laxa & HQ846947 & I \\
\hline CBS298.31 & Ireland & Unknown & M. laxa & HQ846949 & I \\
\hline MDA12 & United States & Unknown & M. laxa & HQ846948 & I \\
\hline 2319 & Japan & Unknown & Monilia polystroma & HQ856916 & IV \\
\hline CBS102686 & Japan & Unknown & M. polystroma & HQ846944 & IV \\
\hline \multicolumn{6}{|l|}{ Sequences from $\mathrm{NCBI}^{\mathrm{d}}$} \\
\hline Hirodai number 3272 & Japan & P. mume 'Bungo' & M. laxa & AB125612 & I \\
\hline DAOM 231119 & Canada & Wine grape & Monilinia fructicola & AY289185 & VI \\
\hline LH01 & Hangzhou, China & Red Bayberry & M. fructicola & AM887528 & VI \\
\hline Hirodai number 2636 & Japan & Unknown & M. fructicola & $\mathrm{AB} 125615$ & VI \\
\hline Hirodai number 3266 & Japan & P. mume 'Ryukyo' & M. fructicola & $\mathrm{AB} 125611$ & VI \\
\hline $782 . \mathrm{K}=\mathrm{LMK} 12$ & Norway & P. persica & M. fructicola & $\mathrm{Z73777}$ & VI \\
\hline 783. $\mathrm{K}=\mathrm{LMK} 125$ & Norway & P. persica & M. fructicola & $\mathrm{Z} 73778$ & VI \\
\hline THF-1 & Shandong, China & Peach & M. fructicola & FJ515894 & VI \\
\hline W1 & Spain & Stone fruit & M. fructicola & EF207420 & VI \\
\hline W11 & Spain & Stone fruit & M. fructicola & EF207422 & VI \\
\hline 99.2.G5.04 & USA & Unknown & M. fructicola & DQ314730 & VI \\
\hline BGA.27.04 & USA & Unknown & M. fructicola & DQ314727 & VI \\
\hline IHEM & Belgium & Pear & M. fructigena & FJ515296 & III \\
\hline
\end{tabular}

(continued on next page)

a "Peach" includes peach, nectarine, flat peach, and flat nectarine.

b Isolates were used in pathogenicity test and phylogenetic analysis.

${ }^{c}$ Isolates could not be identified to the species level using species-specific primers designed by Ioos and Frey (16), as the DNA of each of these isolates generated polymerase chain reaction products in reaction with more than one species-specific primer.

d National Center for Biotechnology Information. 


\begin{tabular}{|c|c|c|c|c|c|}
\hline Isolate & Location & Host $^{\mathrm{a}}$ & Species & $\begin{array}{c}\text { GenBank accession } \\
\text { number }\end{array}$ & $\begin{array}{c}\text { Phylogenetic } \\
\text { group }\end{array}$ \\
\hline LHF-1 & Shandong, China & Pear & M. fructigena & FJ515891 & III \\
\hline COY2M & France & P. insititia & M. fructigena & AF150680 & III \\
\hline COY2N & France & P. persica & M. fructigena & AF150678 & III \\
\hline LAI1B & France & Malus pumila & M. fructigena & AF150677 & III \\
\hline VIC3B & France & $P$. insititia & M. fructigena & AF150679 & III \\
\hline $3 F G$ & Hungary & Cydonia oblon & M. fructigena & AM937109 & III \\
\hline Hirodai number 1145 & Japan & M. pumila var. domestica & M. fructigena & AB125616 & III \\
\hline $1079 . \mathrm{K}$ & Norway & P. domesticus & M. fructigena & Z73781 & III \\
\hline 759.K & Norway & M. domestica & M. fructigena & Z73779 & III \\
\hline $770 . S$ & Norway & M. domestica & M. fructigena & Z73780 & III \\
\hline ES41 & Spain & Unknown & M. fructigena & EF207429 & III \\
\hline ES45 & Spain & Unknown & M. fructigena & EF207427 & III \\
\hline ES49 & Spain & Unknown & M. fructigena & EF207425 & III \\
\hline ES51 & Spain & Unknown & M. fructigena & EF207426 & III \\
\hline W13 & Spain & Unknown & M. fructigena & EF207428 & III \\
\hline W17 & Spain & Unknown & M. fructigena & EF207424 & III \\
\hline UASWS0333 & Switzerland & M. domestica & M. fructigena & EU098121 & III \\
\hline MAFF 960 & Japan & Malus & Monilia polystroma & Y17876 & IV \\
\hline sh675 & Chile & Plum & Monilinia laxa & EU042149 & I \\
\hline BUL1A1 & France & P. insititia & M. laxa & AF150676 & I \\
\hline COY1B5 & France & P. insititia & M. laxa & AF150674 & $\mathrm{I}$ \\
\hline LUC02B1 & France & P. insititia & M. laxa & AF150675 & $\mathrm{I}$ \\
\hline LUC1A & France & P. insititia & M. laxa & AF150673 & I \\
\hline Hirodai number 2646 & Japan & P. mume & M. laxa & AB 125618 & I \\
\hline 1067.K & Norway & M. domestica & M. laxa & Z73784 & I \\
\hline 1078.K & Norway & $P$. persica & M. laxa & Z73785 & I \\
\hline 1083.K & Norway & P. avium & M. laxa & Z73786 & I \\
\hline $1680 . \mathrm{K}$ & Norway & P. avium & M. laxa & Z73787 & I \\
\hline ES 14 & Spain & Stone fruit & M. laxa & EF153016 & I \\
\hline ES 23 & Spain & Stone fruit & M. laxa & EF153017 & I \\
\hline L 2 & Spain & Stone fruit & M. laxa & EF153013 & I \\
\hline T 3 & Spain & Stone fruit & M. laxa & EF153014 & I \\
\hline T 5 & Spain & Stone fruit & M. laxa & EF153015 & I \\
\hline NW522 & China & Unknown & M. fructigena & EU622274 & V \\
\hline
\end{tabular}

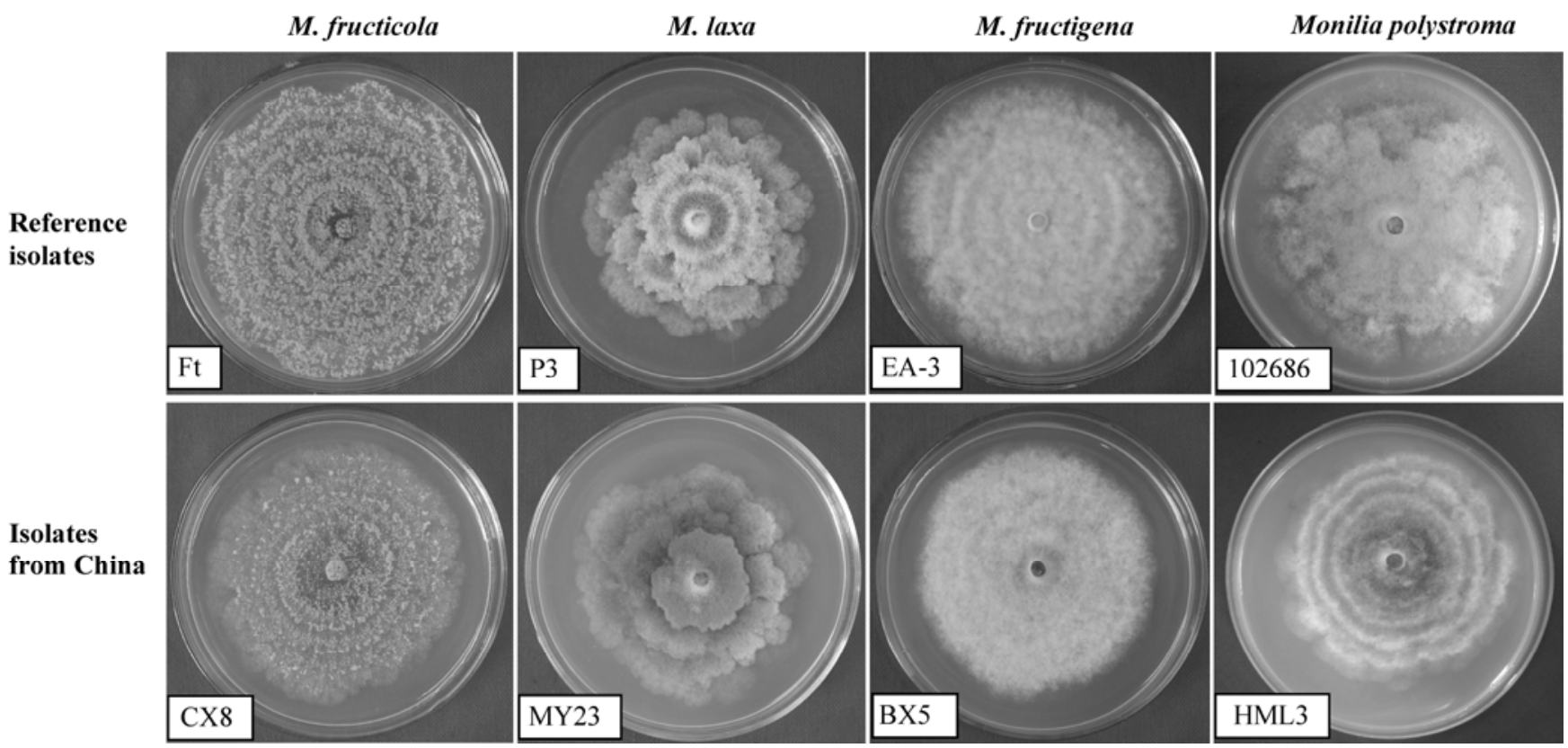

Fig. 1. Colony morphology of Monilinia fructicola, M. laxa, M. fructigena, and Monilia polystroma from China and of the respective reference isolates grown on potato dextrose agar for 6 days.

fructigena based on morphology generated PCR products only with primer pair ITS1Mfgn/ITS4Mfgn. Five isolates, including three isolates identified as $M$. fructicola based on morphology, produced amplification fragments with both ITS1Mfcl/ITS4Mfcl and ITSMfgn/ITS4Mfgn. Two isolates identified as M. laxa and two identified as $M$. fructigena based on morphological characteristics produced amplification fragments with both ITS1Mlx/ ITS4Mlx and ITS1Mfgn/ITS4Mfgn (Fig. 2).
Sequence analysis and phylogeny of brown rot fungi. The ITS region amplified by primers ITS1 and ITS4 (32) included the regions 1 and 2 of the ITS rDNA sequence and the $5.8 \mathrm{~s}$ rDNA gene. The amplified PCR products ranged from 537 to $538 \mathrm{bp}$, and 421 informative nucleotides of each sequence were used in the analysis.

When the ITS sequences of 39 strains from China were compared with the reference sequences retrieved from GenBank, the 
sequences of 22 isolates, including 17 identified as M. fructicola based on morphology and molecular identification, were nearly identical to the reference sequences of $M$. fructicola, such as GenBank accession number Z73777 (14), with the exception of some base pair point mutations; therefore, they were identified as $M$. fructicola. The ITS sequence of an isolate from Heilongjiang was identical to that of the reference isolates of Monilia polystroma, Y17876 (9) and CBS102686 (30); therefore, it was identified as $M$. polystroma. The sequences of six isolates, including four identified as M. laxa based on morphology and molecular identification, were similar in most respects to those of the reference isolates of M. laxa but differed from them by base substitution in two positions within the ITS1 region and in one position within the ITS2 region (Fig. 3); therefore, they were identified as $M$. laxa. The sequences of 10 isolates, including 8 identified as $M$. fructigena based on morphology and molecular identification, were similar in most respects to those of the reference isolates of M. fructigena but differed from them by base substitution in six positions within the ITS1 region and five positions within the ITS2 region (Fig. 3); these isolates were identified as M. fructigena.

Phylogenetic analysis based on the ITS sequence divided the 39 isolates from China and 57 non-China isolates into six groups (Fig. 4). All the non-China isolates of M. laxa were clustered into group I and those from China were clustered into group II. All the nonChina isolates of $M$. fructigena were clustered into group III. The Monilia polystroma isolates from Japan and the isolate from China were clustered together in group IV. Those isolates of M. fructigena from China were clustered in group V. All the isolates of $M$. fructicola were clustered in group VI (Fig. 4). Almost no polymorphism in ITS sequences was found within isolates of each group.
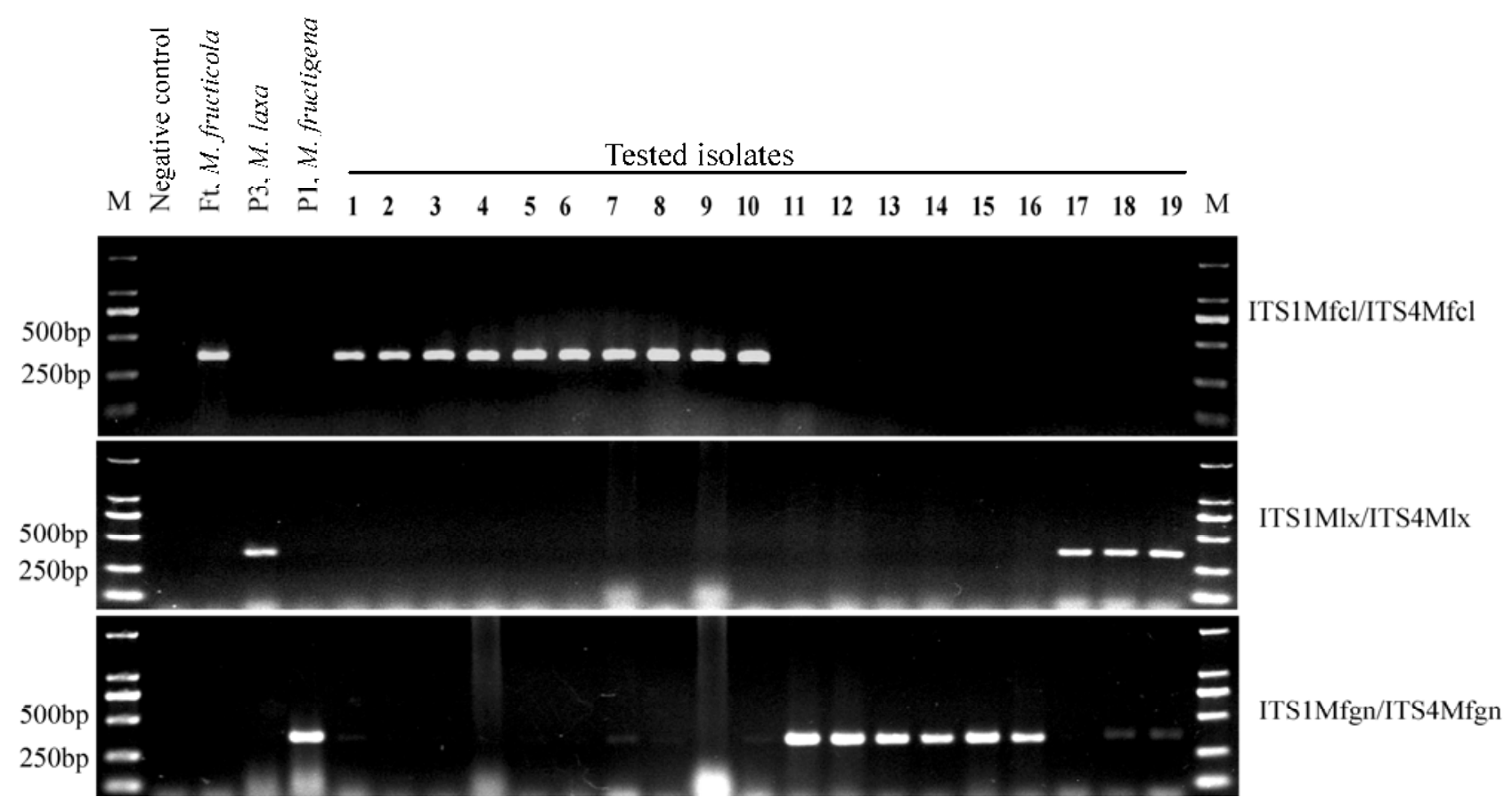

Fig. 2. Polymerase chain reaction (PCR) products obtained using the species-specific primers designed by loos and Frey (16). Ft, $P 3$, and P1 are reference isolates of Monilinia fructicola, M. laxa, and M. fructigena, respectively. Lane 1-19 are isolates from China: 332331, BHY1, PJH2, DH41, T18, CX3, ZJMF1, NB1, PA18, DH11, GP18, GP7, YA1, GDY1-1, GDT1, HML3, STT2, MY11, and JX9. ITS = internal transcribed spacer.

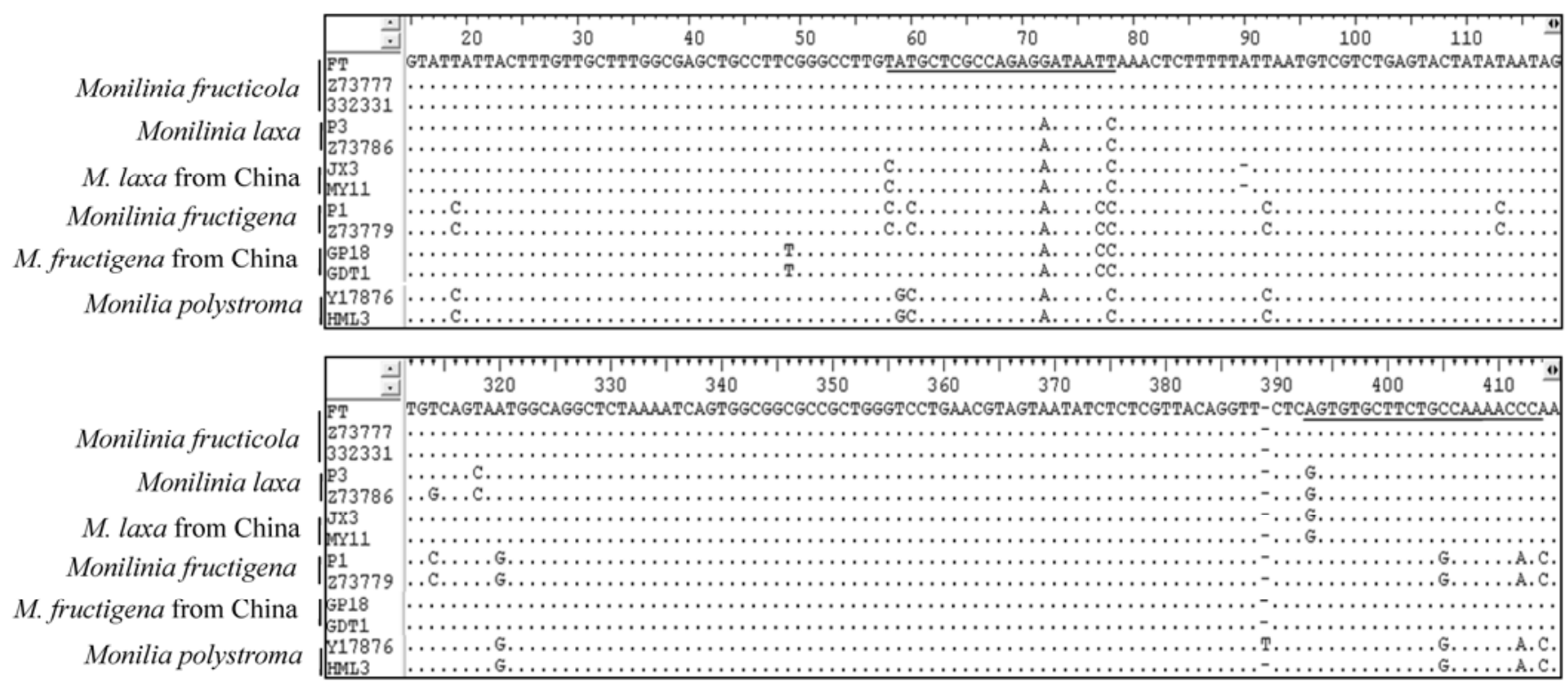

Fig. 3. Sequence alignment of the internal transcribed spacer (ITS)1 and ITS2 regions showing the species-specific base substitutions and the regions (underlined) that were used for the design of the species-specific primers of three Monilinia spp. (16). 
Species composition of brown rot fungi in China. Based on the morphological characteristics, the molecular identification, and the ITS sequence analysis, 423 of the 455 isolates were $M$. fructicola, 22 were $M$. fructigena, 9 were $M$. laxa, and 1 was Monilia polystroma (Tables 2 and 3). Among the isolates from peach in Beijing, 98.8\% were $M$. fructicola and the rest were $M$. fructigena; M. laxa was not isolated from peach in Beijing (Table 2). M. laxa was detected on cherry in one organic orchard in Beijing, on apricot in two orchards in Beijing, and on wild peach in Shandong (Table 2). Monilia polystroma was detected only in a plum orchard in Heilongjiang province, which is in the northeast of China and is close to Japan (the country in which M. polystroma was first reported).

Pathogenicity of the isolates. Fruit inoculated with each of the tested isolates developed brown rot symptoms after 2 to 4 days

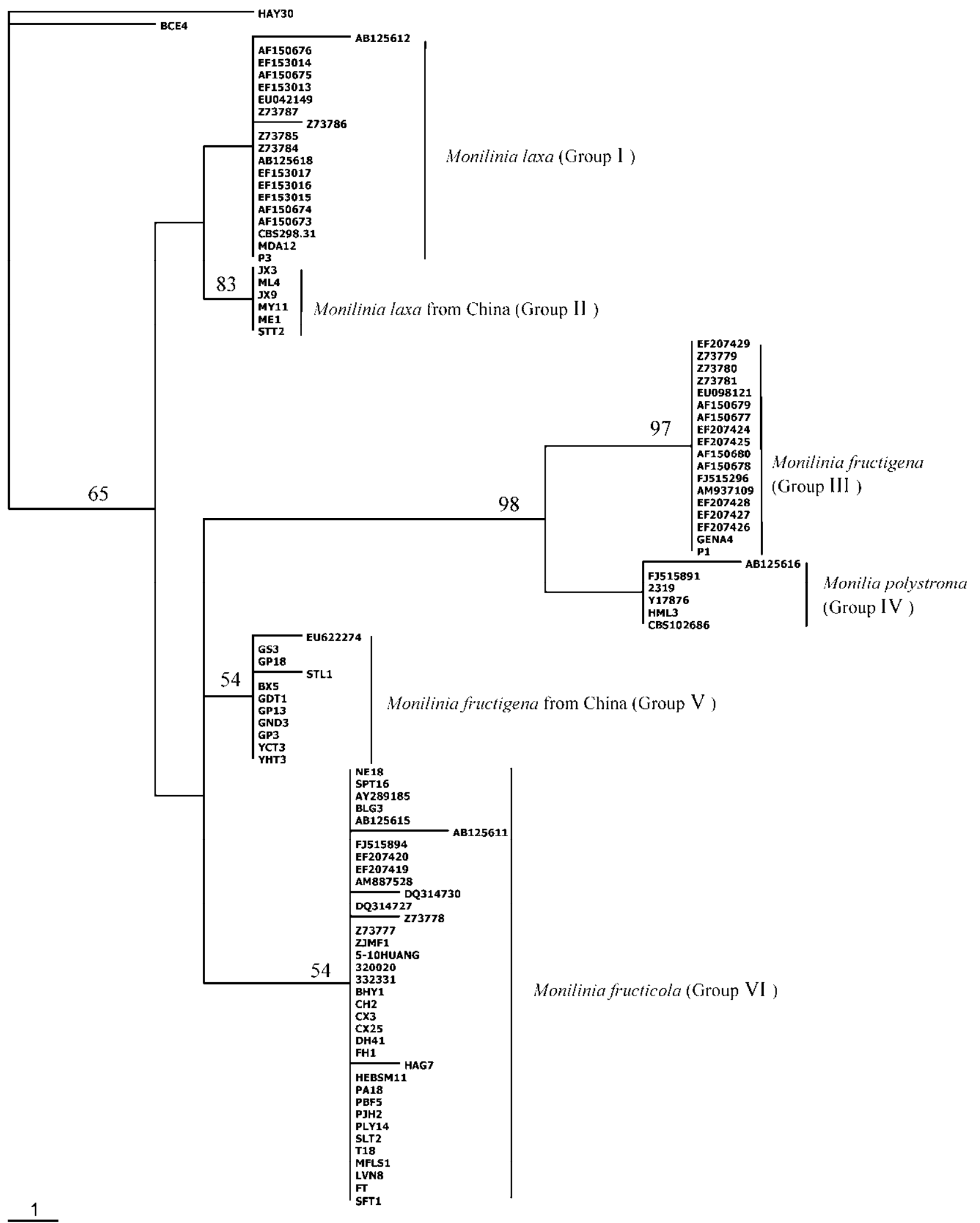

Fig. 4. Phylogenetic tree generated from a maximum parsimony analysis of a data set of internal transcribed spacer sequences of 97 isolates. Bootstrap values $(\geq 50 \%)$ are indicated near the branches. 
while the control fruit remained healthy. The lesion expansion rate on nectarine was 23.0 to $24.5 \mathrm{~mm}$ per day between the second and fourth day after inoculation; the lesion expansion rate on nectarine did not differ among the isolates (ANOVA, $P>0.05$ ). The lesion expansion rate on apricot was 28.6 to $33.9 \mathrm{~mm}$ per day between the second and the fourth day after inoculation; the lesion expansion rate on apricot fruit was slower with isolate JX3 than with the other isolates (ANOVA, $P<0.05$ ) but lesion expansion rate did not significantly different among isolates of different species (ANOVA, $P$ $<0.05)$.

\section{Discussion}

This study represents the first attempt to identify species of brown rot fungi in an extensive collection from stone fruits in China and based on a combination of morphological characterization, a molecular identification method, and ITS sequences. Four species were identified in China, and the results revealed a more complex species composition than previously recognized (31). Among the four species, M. fructicola was dominant, followed by $M$. fructigena, M. laxa, and Monilia polystroma. Among the identification methods used, morphological identification is the simplest but it is time consuming. Moreover, it is difficult to distinguish some $M$. fructicola isolates from $M$. fructigena isolates based on morphology when spores are not produced.

M. fructicola has been thought to be restricted to North America and Australia (3) but it was reported recently in France, China, Italy, Spain, Switzerland, the Czech Republic, Hungary, Slovak Republic, and Slovenia $(2,5,6,12,15,20,22,25-27,35)$. The current results indicate that $M$. fructicola is the most prevalent brown rot fungus on stone fruit in China. A recent study based on genetic diversity of $M$. fructicola populations (8) suggested that $M$. fructicola occurred in China long before it was discovered in 2004 (35). Moreover, $M$. fructicola was recently detected in several provinces of southern China (18). Although M. laxa is reported to be distributed worldwide (3) and to be widely distributed in China (31), the current study detected $M$. laxa only infrequently. Because $M$. fructicola is the most prevalent brown rot fungus on stone fruit in China, it should be treated as the major target in selection of management strategies for control of brown rot on stone fruit in most areas in China.

In this study, an uneven number of isolates was obtained from different locations and different hosts. This is mainly due to the uneven distribution of the hosts across the country and to differences in disease incidence on different hosts. First, most stone fruit in China are produced in the eastern part of the country. In addition, peach (including peach, nectarine, flat peach, and flat nectarine, which usually are grown together in the same orchard) is the major stone fruit crop, and plum, cherry, and apricot are minor crops that are usually grown in small orchards or in small sections of orchards. Moreover, brown rot on peach is common but brown rot on other Prunus spp. is uncommon, perhaps because the fruit of these other Prunus spp. is harvested before the rainy season, which is in July and August for most parts of China.

The pathogenicity test in this study showed that the virulence of three species did not significantly differ on wounded fruit. Therefore, we infer that the low incidence of M. laxa and M. fructigena on stone fruit was not the result of low virulence. Previous research has shown that a wound is essential for infection of $M$. fructigena on apple (34). Because only one isolate of Monilia polystroma was detected, it was not included in the comparison of pathogenicity between species, even though this species can cause brown rot on plum and apple (36).

The current results also showed that the isolates of M. laxa and M. fructigena from China differed from isolates from other locations based on ITS sequences (Fig. 3). Some of the point mutations were located within the region of species-specific primers designed by Ioos and Frey (16; Fig. 3), and this might explain the failure in species identification with these species-specific primers. Although the difference between the ITS sequence of isolates from China and the isolates from outside China were lim- ited to a few bases, the sequences within each group were highly consistent, and the differences separated them into different phylogenetic groups.

For the identification of some isolates belonging to the six phylogenetic groups, we have tested the two sets of primers that were recently developed based on $c y t b$ genes $(13,19)$. The primers of Hily et al. (13) could not distinguish the isolates of M. laxa (from China) from the reference isolate of $M$. fructicola, or the isolates of $M$. fructigena (from China) from the reference isolates of $M$. laxa (unpublished data). Similarly, the primers of Miessner et al. (19) could not differentiate M. laxa from China from Monilia polystroma isolate CBS102686 or M. fructigena (i.e., PCR products of similar size were amplified; unpublished data). These unpublished results suggest that the cytb gene of $M$. laxa and $M$. fructigena from China may differ the $c y t b$ gene of $M$. laxa and $M$. fructigena from other countries.

Because consistent differences in biological characters have not been found between the isolates of M. laxa from China and those from outside China, or between isolates of $M$. fructigena from China and those from outside China, further study is needed to determine whether cryptic species exist in populations of $M$. laxa and M. fructigena. Moreover, because China is within the center of origin of several stone fruit (24), it is possible that China is also within the center of origin of some Monilinia spp. Therefore, analyses based on sequences of multiple genes of brown rot fungi from China and the surrounding areas may increase our understanding of the evolution of these fungi.

\section{Acknowledgments}

This work was supported by the International Foundation for Science (D/3938-1) and the Earmarked Fund for Modern Agro-industry Technology Research System (CARS-28). We thank Z.-H. Ma and H.-Y. Li of Zhejiang University, J.-P. Li of the Institute of Plant Protection of Academy of Gansu Agricultural Science, X.-J. Li of the Academy of Shandong Agricultural Science, and D.-F. Liu of the Academy of Mudanjiang Agricultural Science for their help with sample collection; and R. Ioos of LNPV in France for providing some of the reference isolates and B. Jaffee for editing the manuscript.

\section{Literature Cited}

1. Anonymous. 2007. List of quarantine pests of entry plants for China. (In Chinese.) http://dzwjyjgs.aqsiq.gov.cn/zwjyjy/swaq/wlyhsw/200706/t20070 607_31809.htm

2. Bosshard, E. H. M. S. 2006. First report of the quarantine brown rot pathogen Monilinia fructicola on imported stone fruits in Switzerland. Plant Dis. 90:1554.

3. Byrde, R. J. W., and Willettes, H. J. 1977. The Brown Rot Fungi of Fruit: Their Biology and Control. Pergamon Press, Oxford

4. Dai, F. L., Xiang, W. N., and Zheng, R. Y. 1958. List of Pathogens on Chinese Economic Plants. Science Press, Beijing.

5. De Cal, A., Gell, I., Usall, J., Vinas, I., and Melgarejo, P. 2009. First report of brown rot caused by Monilinia fructicola in peach orchards in Ebro Valley, Spain. Plant Dis. 93:763.

6. Duchoslavová, J., Širucková, I., Zapletalová, E., Navrátil, M., and Šafárová D. 2007. First report of brown rot caused by Monilinia fructicola on various stone and pome fruits in the Czech Republic. Plant Dis. 91:907.

7. EPPO/CABI. 1997. Quarantine Pests for Europe. CAB International, Wallingford, UK

8. Fan, J. Y., Guo, L. Y., Xu, J. P., Luo, Y., and Michailides, T. 2010. Genetic diversity of populations of Monilinia fructicola (Fungi, Ascomycota, Helotiales) from China. J. Eukaryot. Microbiol. 57:206-212.

9. Fulton, C. E., van Leeuwen, G. C. M., and Brown, A. E. 1999. Genetic variation among and within Monilinia species causing brown rot of stone and pome fruits. Eur. J. Plant Pathol. 105:495-500.

10. Guo, L. Y., Zhu, X. Q., Hu, C. H., and Ristaino, J. B. 2010. Genetic structure of Phytophthora infestans populations in China indicates multiple migration events. Phytopathology 100:997-1006.

11. Hall, T. 1999. BioEdit: a user-friendly biological sequence alignment editor and analysis program for Windows 95/98/NT. Nucleic Acids Symp. Ser. 41:95-98.

12. Hilber-Bodmer, M., Bünter, M., and Patocchi, A. 2010. First report of brown rot caused by Monilinia fructicola on apricot in a Swiss orchard. Plant Dis. 94:643.

13. Hily, J., Singer, S. D., Villani, S. M., and Cox, K. D. 2011. Characterization of the cytochrome $b$ ( $c y t b$ ) gene from Monilinia species causing brown rot of stone and pome fruit and its significance in the development of QoI resistance. Pest Manage. Sci. 67:385-396.

14. Holst-Jensen, A., Kohn, L. M., Jakobsen, K. S., and Schumacher, T. 1997. Molecular phylogeny and evolution of Monilinia (Sclerotiniaceae) based on 
coding and non-coding rDNA sequence. Am. J. Bot. 84:686-701.

15. Hu, M. J., Chen, Y., Chen, S. N., Liu, X. L., Yin, L. F., and Luo, C. X. 2011. First report of brown rot of peach caused by Monilinia fructicola in southeastern China. Plant Dis. 95:225.

16. Ioos, R., and Frey, P. 2000. Genomic variation within Monilinia laxa, M. fructigena and M. fructicola, and application to species identification by PCR. Eur. J. Plant Pathol. 106:373-378.

17. Lane, C. R. 2002. A synoptic key for differentiation of Monilinia fructicola, $M$. fructigena and $M$. laxa, based on examination of cultural characters. Bull. OEPP/EPPO Bull. 32:489-493.

18. Luo, C. X., Hu, M. J., Jin, X., Yin, L. F., Bryson, P., and Schnabel, G. 2010. An intron in the cytochrome $b$ gene of Monilinia fructicola mitigates the risk of resistance development to QoI fungicides. Pest Manage. Sci. 66:308-319.

19. Miessner, S., and Stammler, G. 2010. Monilinia laxa, M. fructigena and $M$. fructicola: risk estimation of resistance to QoI fungicides and identification of species with cytochrome b gene sequences. J. Plant Dis. Plant Prot. 4:162-167.

20. Munda, A., and Virš ek Marn, M. 2010. First report of brown rot caused by Monilinia fructicola affecting peach orchards in Slovenia. Plant Dis. 94:166.

21. Murray, M., and Thompson, W. 1980. Rapid isolation of high molecular weight plant DNA. Nucleic Acids Res. 8:4321-4325.

22. OEPP/EPPO. 2002. First report of Monilinia fructicola in France. EPPO Reporting Service 2002/003. http://www.EPPO.org

23. OEPP/EPPO. 2009. EPPO A2 List of pests recommended for regulation as quarantine pests. http://www.eppo.org/QUARANTINE/listA2.htm

24. Ogawa, J. M., Zehr, E. I., and Bird, W. 1995. Brown rot. Page 7-10 in: Compendium of Stone Fruit Diseases. J. M. Ogawa, E. I. Zehr, G. W. Bird, D. F. Ritchie, K. Uriu, and J. K. Uyemoto, eds. American Phytopathological Society, St. Paul, MN.
25. Ondejkova, N., Hudecova, M., and Bacigalova, K. 2010. First report on Monilinia fructicola in the Slovak Republic. Plant Prot. Sci. 46:181-184.

26. Pellegrino, C., Gullino, M. L., Garibaldi, A., and Spadaro, D. 2009. First report of brown rot of stone fruit caused by Monilinia fructicola in Italy. Plant Dis. 93:668.

27. Petroczy, M., and Palkovics, L. 2006. First report of brown rot caused by Monilinia fructicola on imported peach in Hungary. Plant Dis. 90:375.

28. Petróczy, M., and Palkovics, L. 2009. First report of Monilia polystroma on apple in Hungary. Eur. J. Plant Pathol. 125:343-347.

29. Swoford, D. L. 2000. PAUP: Phylogenetic Analysis Using Parsimony. Sinauer Associates, Sunderland, MA.

30. van Leeuwen, G. C. M. Yen, R. P. B., Holb, I. J., and Jeger, M. 2002 Distinction of the Asiatic brown rot fungus Monilia polystroma sp. nov. from M. fructigena. Mycol. Res. 106:444-451.

31. Wang, Y. X., Wang, G., Zeng, Q. C., and Zhang, Z. Y. 1998. Studies on the investigation and integrated control of brown rot disease of peach (Monilia sp.). J. Yunnan Agric. Univ. 1:29-32.

32. White, T. J., and Bruns, T. 1990. Amplification and direct sequencing of fungal ribosomal RNA genes for phylogenetics. Pages 315-322 in: PCR Protocols: A Guide to Methods and Applications. M. A. Innis, D. H. Gelfand, J. J. Sninsky, and T. J. White, eds. Academic Press, New York.

33. Wilson, K. 1990. Preparation of Genomic DNA from Bacteria. Pages 241245 in: Current Protocols in Molecular Biology. F. Ausubel and R. Brent, eds. Wiley Interscience, New York.

34. Xu, X. M., and Robinson, J. D. 2000. Epidemiology of brown rot (Monilinia fructigena) on apple: infection of fruits by conidia. Plant Pathol. 49:201-206.

35. Zhu, X. Q., Chen, X. Y., Guo, L. Y., and Luo, Y. 2005. First report of Monilinia fructicola on peach and nectarine in China. Plant Pathol. 54:576.

36. Zhu, X. Q., and Guo, L. Y. 2010. First report of brown rot on plum caused by Monilia polystroma in China. Plant Dis. 94:478. 